Citation: A. I. Santosa, F. Ertunc (2021) Characterization of two Cucumber mosaic virus isolates infecting Allium cepa in Turkey. Phytopathologia Mediterranea 60(1): 13-21. doi: 10.36253/ phyto-11840

Accepted: September 22, 2020

Published: May 15, 2021

Copyright: (c) 2021 A. I. Santosa, F. Ertunc. This is an open access, peerreviewed article published by Firenze University Press (http://www.fupress. $\mathrm{com} / \mathrm{pm}$ ) and distributed under the terms of the Creative Commons Attribution License, which permits unrestricted use, distribution, and reproduction in any medium, provided the original author and source are credited.

Data Availability Statement: All relevant data are within the paper and its Supporting Information files.

Competing Interests: The Author(s) declare(s) no conflict of interest.

Editor: Anna Maria D'Onghia, CIHEAM/Mediterranean Agronomic Institute of Bari, Italy.

\section{Short Notes \\ Characterization of two Cucumber mosaic virus isolates infecting Allium cepa in Turkey}

\author{
AdyATMa I. SANTOSA*, Filiz ERTUNC \\ Department of Plant Protection, Faculty of Agriculture, Ankara University, 06110 Dis- \\ kapi, Ankara, Turkey \\ ${ }^{\star}$ Corresponding author. E-mail: adyatma_santosa@yahoo.com
}

Summary. Cucumber mosaic virus (CMV) is polyphagous, infecting plants in several families. CMV has occurred as a minor pathogen in Allium crops in several Mediterranean countries, but little was known of the virus naturally infecting Allium spp. This study completed molecular and biological characterization of CMV-14.3Po and CMV-15.5Po, two newly identified CMV isolates infecting onion (Allium cepa L.) in Turkey. Phylogenetic, and nucleotide and amino acid sequence identity analyses of partial RNA2 and RNA3 of the two isolates showed that they were very similar to other CMV isolates from Mediterranean, European, and East Asian countries. Phylogenetic analysis of the partial sequence of RNA3 also showed that the onion isolates belong to subgroup IA. Onion isolates were mechanically transmissible, and caused mild leaf malformation on onion, severe leaf malformation and stunting on garlic (Allium sativus L.), and mosaic and mottle on cucumber (Cucumis sativus L.) and melon (Cucumis melo L.).

Keywords. Onion, phylogenetic analysis, host indexing.

\section{INTRODUCTION}

Allium crops, including onion (Allium cepa L.), garlic (Allium sativus L.), and leek (Allium ampeloprasum L.), have been reported to be infected by viruses belonging to Potyvirus, Carlavirus, Tospovirus, and Allexivirus (Shahraeen et al., 2008; Tomassoli et al., 2009; Parrano et al., 2012). Several of these viruses, including Leek yellow stripe virus (LYSV), Onion yellow dwarf virus (OYDV), Iris yellow spot virus (IYSV), Shallot latent virus (SLV), and Garlic common latent virus (GarCLV), are frequently found in Allium crops (Dovas and Volvas, 2003; Ward et al., 2009; Sevik and Akcura, 2013; Bag et al., 2015; Abraham et al., 2019). Other viruses, including Turnip mosaic virus (TuMV), Shallot yellow stripe virus (SYSV), and Groundnut bud necrosis virus (GBNV), have been considered as minor pathogens that occasionally infect Allium spp. only in particular regions (Gera et al., 1997; Chen et al., 2005; Sujitha et al., 2012).

Cucumber mosaic virus (CMV) (Cucumovirus, Bromoviridae) has a very broad host range. It usually causes diseases on plant in Cucurbitaceae, Sola- 
naceae, Brassicaceae, and Fabaceae, and typically induces mild to severe systemic mosaic symptoms on these plants (Brunt et al., 1996). More than 80 aphid species have been recorded to non-persistently non-circulatively transmit CMV (Palukaitis and Garcia-Arenal, 2003). CMV is a tripartite virus, with the genome in three single-stranded plus-sense RNAs (RNA1-3). RNA1 encodes 1a protein and RNA2 encodes 2 a protein, which are both involved in the replicase complex (Hayes and Buck, 1990). A small 2b protein involved in cell-to-cell movement, suppression of post-transcriptional gene silencing, and symptom induction, is also expressed in RNA2 (Bujarski et al., 2019). RNA3 encodes 3a protein (movement protein (MP)) and coat protein (CP), which are important in viral movement processes (Boccard and Baulcombe, 1993).

CMV was probably first recorded infecting Allium when it was serologically detected in a single garlic sample in Zagreb, Croatia (formerly Yugoslavia) (Stefanac, 1980). A large survey on Allium viruses in the East Mediterranean region of Turkey identified CMV as a minor virus infecting garlic in the area (Fidan, 2010). The CMV-ALC1 isolate was detected in leek in Alicante, Spain, and its nucleotide sequence was registered in NCBI GenBank with accession no. JN806091 (AlfaroFernandez et al., unpublished). These findings showed presence of CMV isolates naturally infecting Allium crops in different Mediterranean regions.

Recently, two onion samples from Ankara province in Turkey tested positive for CMV and negative for LYSV, OYDV, GarCLV, and SLV infections. The two CMV isolates were subsequently named CMV14.3Po and CMV-15.5Po, and the partial nucleotide (nt) sequence of their RNA2 were deposited in NCBI GenBank (accession no. MN070136-37). Initial phylogenetic analysis showed that the isolates were similar to isolates from Iran, Serbia, Hungary, Poland, Germany, Japan, China, and South Korea, which indicated very wide distribution of CMV isolates genetically similar to onion isolates (Santosa and Ertunc, 2020).

The relationship between CMV and Allium spp. still requires investigation, because $\mathrm{CMV}$ is prevalent and many Allium spp. are economically important crops. Wide phylogenetic analyses of partial nt sequences of RNA2 and RNA3, and host indexing of CMV-14.3Po and CMV-15.5Po, are presented in this study, to provide further knowledge about CMV infection in onion and other Allium spp.

\section{MATERIALS AND METHODS}

\section{Nucleotide sequences of RNA2 of onion isolates}

The previously reported partial nt sequences of RNA2 were 521 bp long (Santosa and Ertunc, 2020), covering 27 bp of 5' UTR and 494 bp of partial 2a protein gene (1-494 position), for reference isolate accession no. D10538. These are the only nt sequences of CMV isolates naturally infecting onion that are currently available in NCBI GenBank. Therefore, a portion of their RNA3 was also sequenced in the present study to provide more information about their genetic makeup.

\section{RT-PCR and sequencing of partial RNA3}

Total nucleic acid was extracted from onion samples using tris-EDTA buffer $(100 \mathrm{mM}$ tris, $50 \mathrm{mM}$ EDTA, $500 \mathrm{mM} \mathrm{NaCl}, 10 \mathrm{mM}$ 2-mercaptoethanol, $\mathrm{pH}$ 8.0) (Presting et al., 1995). RT-PCR was performed in two stages (Santosa and Ertunc, 2020). A primer pair F-GTAGACATCTGTGACGCGA and R-GCGCGAAACAAGCTTCTTATC was used in the PCR to amplify 540 bp of RNA3 (De Blas et al., 1994).

PCR cycles were carried out using a thermocycler (Biometra, Germany). Each cycle consisted of initial denaturation at $94^{\circ} \mathrm{C}$ for $5 \mathrm{~min} ; 35$ cycles of denaturation at $94^{\circ} \mathrm{C}$ for $60 \mathrm{~s}$, annealing at $54^{\circ} \mathrm{C}$ for $60 \mathrm{~s}$, elongation at $72^{\circ} \mathrm{C}$ for $60 \mathrm{~s}$, and a final extension at $72^{\circ} \mathrm{C}$ for 10 min. Products were visualized on a $1 \%(\mathrm{w} / \mathrm{v})$ tris-acetate agarose gel stained with ethidium bromide. Successfully amplified RT-PCR products were sent to BM Lab. Ltd. (Ankara, Turkey) for purification and Sanger sequencing. The obtained nt sequences were then submitted to NCBI GenBank.

Neighbor-joining tree construction, and nucleotide and amino acid sequences identity percentage calculation

Genes that were homologous to Turkish onion isolates were determined using the BLAST program from the the NCBI website. The Turkish onion isolates were then compared with reference CMV isolates from GenBank. The selected CMV isolates were mostly those which each had both RNA2 and RNA3 sequences available in GenBank. All sequences were aligned using ClustalW version 1.6, with default parameters in MEGA7 software (megasoftware.net). MEGA7 then applied a Neighbor-joining algorithm with both transition and transversion substitutions, and uniform rates, to construct two phylogenetic trees for RNA2 and RNA3 
comparisons (Hall, 2013). Statistical significance of isolate clusters were tested using 1000 bootstrap replicates in the Tamura 3 parameter model (Tamura, 1992). Nucleotide (nt) and amino acid (aa) similarity percentages among tested isolates were estimated using Sequence Demarcation Tool (SDT) v1.2 software (Muhire et al., 2014).

\section{Host indexing}

Each onion isolate of CMV was mechanically inoculated to four onion, garlic, cucumber (Cucumis sativus L.), and melon (Cucumis melo L.) plants, to determine host responses. Prior to inoculation, plants were tested to be CMV-free by RT-PCR. Onion and garlic plants were also tested to be free from LYSV, SLV, GarCLV, and OYDV infections using RT-PCR and specific primers for each virus (Fajardo et al., 2001; Majumder et al., 2008; Parrano et al., 2012; Nam et al., 2015).

Plant sap was prepared by grinding $1 \mathrm{~g}$ of naturally infected onion leaf samples in $5 \mathrm{~mL}$ of $0.01 \mathrm{M}$ potassium phosphate buffer ( $\mathrm{pH} 7)$ using a mortar and pestle. Leaves of treated plants were dusted with abrasive-celite, then plant sap was manually rubbed on the leaves. Four onion, garlic, cucumber, and melon plants were each dusted with abrasive-celite then rubbed with potassium phosphate buffer as controls. Ten minutes after treatment, inoculated and control plants were rinsed with distilled water. The plants were then kept in a greenhouse at $24-28^{\circ} \mathrm{C}$, and any symptoms were recorded during the following 2 to 5 weeks (Hill, 1984; Ohno et al., 1997; Hull, 2009). At 5 weeks after inoculation, a composite sample of leaves of the inoculated plants of the each species were collected for RT-PCR. This allowed onion isolates infection on each plant species to be confirmed by a small number of RT-PCRs, but infection rates were unknown. A primer pair of F-GTTTATTTACAAGAGCGTACGG and R-GGTTCGAA(AG)(AG)(AT)ATAACCGGG, to amplify 650 bp of RNA2, was used in the PCR (Finetti Sialer et al., 1999).

\section{RESULTS}

\section{Sequencing of RNA3}

The obtained partial nt sequences of RNA3 were 540 bp long, covering 216 bp of 5' UTR and 324 bp of the partial CP gene (1-324 position) for reference isolate accession no. D10538. NCBI GenBank accession no. MN864792-93 were acquired for them.
Phylogenetic analysis and nucleotide and amino acid sequences identity percentage

The phylogenetic tree constructed based on the partial RNA2 comparison was divided into four groups (1-4). The two onion isolates clustered with 21 other isolates in Group 1. The tree constructed based on the partial RNA3 comparison was also divided into four groups (1-4). However, the onion isolates only clustered in Group 1 with 15 other CMV isolates, which showed that not all isolates used in this study had high identities to the onion isolates in their RNA2 and RNA3 sequences (Figure 1).

CMV-14.3Po and CMV-15.5Po shared very high nt and aa sequence similarities in both RNA2 and RNA3. All the compared CMV isolates showed high nt (91.2$99.4 \%)$ and aa (89-100\%) in partial RNA2 to onion isolates. The compared CMV isolates showed relatively lower nt (86.7-99.8\%) and aa (81.8-100\%) sequences to the onion isolates in comparison of partial RNA3 (Table 1).

TUR84, TUR86, I17F, PV0187, Ns, Rs, Gd, Ri-8, CMV21, NND454J and Can isolates had very high nt and aa similarities in both RNA2 and RNA3 sequences to the onion isolates, and also were clustered in the same group with onion isolates in both phylogenetic trees. The outcome showed that these isolates were genetically more similar to CMV Turkish onion isolates than the other virus isolates compared in this study.

\section{Host indexing}

Both of the onion isolates caused mild leaf malformations on all the inoculated onion plants, which was difficult to differentiate from the controls. Severe leaf malformations and stunting were observed on all inoculated garlic plants. Mottle symptoms appeared on leaves of most of the cucumber and melon plants inoculated with both onion isolates. Only one cucumber and one melon plant produced clear mosaic symptoms after inoculation with isolate CMV-14.3Po (Table 2; Figure 2). Infections on all the tested plant species were confirmed by RT-PCR (Figure 3).

\section{DISCUSSION}

Based on partial RNA2 and RNA3 sequence comparisons, the two onion isolates (CMV-14.3Po and CMV15.5Po) had high similarities to at least 11 other CMV isolates. Some of these other isolates were also originally from Turkey, while some were from geographically close countries (Iran, Hungary, Germany, Austria, 


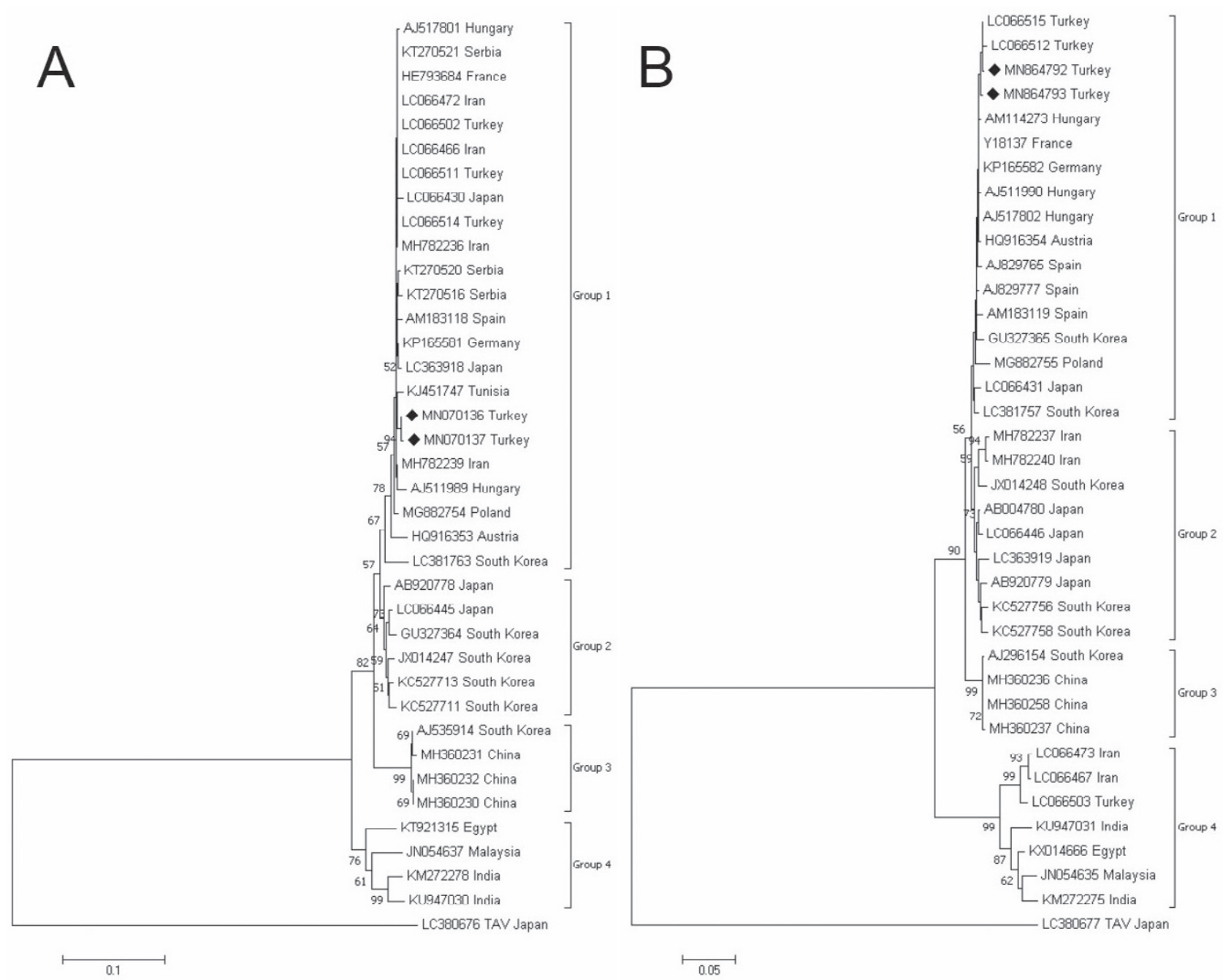

Figure 1. A. Phylogenetic tree based on nucleotide sequence comparisons of partial RNA2 of two onion isolates (MN070136-37) and 35 other CMV isolates. B. Phylogenetic tree based on nucleotide sequence comparisons of partial RNA3 of two onion isolates (MN86479293) and 35 other CMV isolates. Bootstrap values on each branch were supported by 1000 replicates, and only values greater than $50 \%$ are shown. An isolate of Tomato aspermy virus (TAV Japan) was used as out-group.

France, Spain, and Poland), and some others were from East Asian countries (South Korea and Japan). The two onion isolates were also similar to three Serbian isolates (650-07, 581-11, and 473-12) and one Tunisian isolate (89-2012) only in the RNA2 sequence comparisons, since these isolates have no information on their RNA3 sequences available in NCBI GenBank. In only the RNA3 sequence comparisons, the two onion isolates were highly homologous to one Hungarian isolate (Le02) and two Spanish isolates (MAD01/2 and BAR96/1).

There is no sequence of CMV isolates from Croatia available in NCBI GenBank to be compared to onion isolates examined in the present study, but the onion isolates were very similar to isolates from Serbia, Hungary, and Austria, which are direct neighbours of Croatia. Thus, there was possibility that the CMV garlic isolate (CMV-G) that was reported in Croatia (Stefanac, 1980) also had high nt sequence similarities to CMV-14.3Po and CMV-15.5Po.

Two Iranian CMV isolates (IRN-REY4 and IRNREY10) and one Turkish isolate (TUR54) all from radish (Raphanus sativus L.) were very similar in RNA2 sequences, but were divergent in RNA3 sequences, in comparison to the two onion isolates. These isolates clustered together with onion isolates in Group 1 of the phylogenetic tree of RNA2, but clustered in Group 4 of the tree of RNA3, which was very distant to the onion isolates. The RNA3 of CMV was known to be little conserved, as was also shown by the sequences iden- 
Tabel 1. CMV isolates used in this study. The partial RNA2 and RNA3 nucleotide and amino acid sequence percentages to onion isolates are indicated.

\begin{tabular}{|c|c|c|c|c|c|c|c|c|c|c|c|}
\hline \multirow[b]{2}{*}{ No. } & \multirow{2}{*}{$\begin{array}{l}\text { Isolate } \\
\text { name }^{\text {a }}\end{array}$} & \multirow[b]{2}{*}{ Origin } & \multirow[b]{2}{*}{ Host } & \multicolumn{4}{|c|}{ RNA2 comparison } & \multicolumn{4}{|c|}{ RNA3 comparison } \\
\hline & & & & $\begin{array}{c}\text { Accession } \\
\text { No. }\end{array}$ & $\begin{array}{l}\text { Phylo } \\
\text { group }\end{array}$ & $\begin{array}{l}\text { nt identity } \\
(\%)\end{array}$ & $\begin{array}{c}\text { aa identity } \\
(\%)\end{array}$ & $\begin{array}{l}\text { Accession } \\
\text { No. }\end{array}$ & $\begin{array}{l}\text { Phylo } \\
\text { group }\end{array}$ & $\begin{array}{l}\text { nt identity } \\
(\%)\end{array}$ & $\begin{array}{l}\text { aa identity } \\
(\%)\end{array}$ \\
\hline 1. & $14.3 \mathrm{Po}^{\mathrm{b}}$ & Turkey & Allium cepa & MN070136 & 1 & 100 & 100 & MN864792 & 1 & 100 & 100 \\
\hline 2. & $15.5 \mathrm{Po}^{\mathrm{b}}$ & Turkey & Allium cepa & MN070137 & 1 & 100 & 100 & MN864793 & 1 & 100 & 100 \\
\hline 3. & Rs & Hungary & Raphanus sativus & AJ517801 & 1 & $99.0-99.2$ & 99.4 & AJ517802 & 1 & $99.4-99.6$ & 100 \\
\hline 4. & IRN-REY4 & Iran & Raphanus sativus & LC066466 & 1 & $99.2-99.4$ & 100 & LC066467 & 4 & $87.8-88.3$ & 83.5 \\
\hline 5. & TUR86 & Turkey & Rapistrum rugosum & LC066514 & 1 & $99.2-99.4$ & 100 & LC066515 & 1 & $99.6-99.8$ & 100 \\
\hline 6. & TUR84 & Turkey & Rapistrum rugosum & LC066511 & 1 & $99.2-99.4$ & 100 & LC066512 & 1 & $99.3-99.4$ & 99.4 \\
\hline 7. & TUR54 & Turkey & Raphanus sativus & LC066502 & 1 & $99.2-99.4$ & 100 & LC066503 & 4 & $87.8-88$ & 81.8 \\
\hline 8. & MeEs & Iran & Cucumis melo & MH782236 & 1 & $99.2-99.4$ & 100 & MH782237 & 2 & $97.0-97.2$ & 98.9 \\
\hline 9. & IRN-REY10 & Iran & Raphanus sativus & LC066472 & 1 & $99.2-99.4$ & 100 & LC066473 & 4 & $87.6-88.1$ & 83 \\
\hline 10. & NND454J & Japan & Raphanus sativus & LC066430 & 1 & $98.7-98.8$ & 100 & LC066431 & 1 & $98.5-98.7$ & 98.3 \\
\hline 11. & I17F & France & Solanum lycopersicum & HE793684 & 1 & $99.2-99.4$ & 100 & Y18137 & 1 & $99.4-99.6$ & 100 \\
\hline 12. & Ri-8 & Spain & Solanum lycopersicum & AM183118 & 1 & $98.7-98.8$ & 100 & AM183119 & 1 & $98.7-98.9$ & 98.9 \\
\hline 13. & PV0187 & Germany & - & KP165581 & 1 & $99.0-99.2$ & 100 & KP165582 & 1 & $99.4-99.6$ & 100 \\
\hline 14. & Co-46 & Japan & Corchorus olitorius & LC363918 & 1 & $98.7-98.8$ & 100 & LC363919 & 2 & $97.0-97.2$ & 98.3 \\
\hline 15. & SqSh & Iran & Cucurbita pepo & MH782239 & 1 & $99.0-99.2$ & 100 & MH782240 & 2 & $97.2-97.4$ & 98.9 \\
\hline 16. & Ns & Hungary & Nicotiana glutinosa & AJ511989 & 1 & $98.5-98.7$ & 99.4 & AJ511990 & 1 & $99.3-99.4$ & 100 \\
\hline 17. & CMV21 & Poland & Cucurbita pepo & MG882754 & 1 & $98.5-98.7$ & 100 & MG882755 & 1 & $97.8-98$ & 96.6 \\
\hline 18. & Gd & Austria & Cucurbita pepo & HQ916353 & 1 & $97.1-97.3$ & 97.1 & HQ916354 & 1 & $99.3-99.4$ & 100 \\
\hline 19. & Can & S. Korea & Canna generalis & LC381763 & 1 & $96.5-96.7$ & 97.7 & LC381757 & 1 & $98.5-98.7$ & 98.9 \\
\hline 20. & $650-07$ & Serbia & Nicotiana tabacum & KT270521 & 1 & $99.2-99.4$ & 100 & - & - & - & - \\
\hline 21. & $581-11$ & Serbia & Capsicum annuum & KT270520 & 1 & $98.9-99$ & 99.4 & - & - & - & - \\
\hline 22. & $473-12$ & Serbia & Citrullus lanatus & KT270516 & 1 & $98.7-98.8$ & 99.4 & - & - & - & - \\
\hline 23. & $89-2012$ & Tunisia & Cynara scolymus & KJ451747 & 1 & $98.9-99$ & 98.8 & - & - & - & - \\
\hline 24. & Le02 & Hungary & $\begin{array}{l}\text { Lycopersicon } \\
\text { esculentum }\end{array}$ & - & - & - & - & AM114273 & 1 & 99.4-99.6 & 100 \\
\hline 25. & MAD01/2 & Spain & Diplotaxis erucoides & - & - & - & - & AJ829765 & 1 & $99.1-99.3$ & 99.4 \\
\hline 26. & BAR96/1 & Spain & Cucumis melo & - & - & - & - & AJ829777 & 1 & $99.1-99.3$ & 99.4 \\
\hline 27. & $\mathrm{KM}$ & Japan & Cucumis melo & - & - & - & - & AB004780 & 2 & $98.0-98.5$ & 98.3 \\
\hline 28. & m1 & Japan & Nicotiana tabacum & AB920778 & 2 & $96.5-96.7$ & 97.7 & AB920779 & 2 & $97.2-97.4$ & 98.3 \\
\hline 29. & TKD766J & Japan & Raphanus sativus & LC066445 & 2 & $96.4-96.5$ & 97.1 & LC066446 & 2 & $97.6-98.1$ & 98.3 \\
\hline 30. & $\mathbf{R b}$ & S. Korea & Rudbeckia hirta & GU327364 & 2 & $96.4-96.5$ & 95.4 & GU327365 & 1 & $98.5-98.7$ & 99.4 \\
\hline 31. & Va & S. Korea & Vigna angularis & JX014247 & 2 & $96.5-96.7$ & 96.5 & JX014248 & 2 & $97.2-97.8$ & 98.3 \\
\hline 32. & RP30 & S. Korea & Capsicum annuum & KC527713 & 2 & $96.5-96.7$ & 97.1 & KC527758 & 2 & $97.0-97.2$ & 97.2 \\
\hline 33. & RP28 & S. Korea & Capsicum annuum & KC527711 & 2 & $96.4-96.5$ & 95.9 & KC527756 & 2 & $97.0-97.2$ & 97.7 \\
\hline 34. & Ly2 & S. Korea & Lilium longiflorum & AJ535914 & 3 & $93.7-93.9$ & 94.2 & AJ296154 & 3 & $96.5-96.7$ & 94.3 \\
\hline 35. & $\mathrm{C} 4$ & China & Lilium spp. & MH360231 & 3 & $93.3-93.5$ & 93.6 & MH360236 & 3 & $96.7-96.9$ & 94.9 \\
\hline 36. & $\mathrm{C6}$ & China & Lilium spp. & MH360232 & 3 & $93.7-93.9$ & 93.6 & MH360237 & 3 & $96.5-96.7$ & 94.3 \\
\hline 37. & $\mathrm{C} 2$ & China & Lilium longiflorum & MH360230 & 3 & $93.7-93.9$ & 93.6 & MH360258 & 3 & $96.7-96.9$ & 94.9 \\
\hline 38. & HM3 & Egypt & Solanum lycopersicum & KT921315 & 4 & $93.1-93.2$ & 91.3 & KX014666 & 4 & $87.8-88.3$ & 83 \\
\hline 39. & CLW2 & Malaysia & Cucumis sativus & JN054637 & 4 & $92.7-92.9$ & 89.6 & JN054635 & 4 & $87.0-87.6$ & 83 \\
\hline 40 & KO & India & Capsicum annuum & KM272278 & 4 & $91.7-91.9$ & 88.4 & KM272275 & 4 & $86.7-87.2$ & 81.8 \\
\hline 41 & ICAR-IISR PN25 & India & Piper nigrum & KU947030 & 4 & $91.2-91.3$ & 89 & KU947031 & 4 & $87.2-87.4$ & 83 \\
\hline
\end{tabular}

a Isolates that name typed in bold are those that both RNA2 and RNA3 sequences are available in NCBI GenBank.

${ }^{\mathrm{b}} \mathrm{CMV}$ onion isolates that were identified in this study. 
Table 2. Symptoms caused from inoculations with two CMV isolates on different inoculated test plants.

\begin{tabular}{|c|c|c|c|c|c|}
\hline \multirow{2}{*}{ Isolate } & \multirow{2}{*}{ Plant species } & \multicolumn{4}{|c|}{ Symptoms on inoculated plant number ${ }^{\mathrm{a}}$} \\
\hline & & 1 & 2 & 3 & 4 \\
\hline \multirow[t]{4}{*}{ CMV-14.3Po } & Onion & Mild leaf malformation & Mild leaf malformation & Mild leaf malformation & Mild leaf malformation \\
\hline & Garlic & $\begin{array}{l}\text { Severe leaf malformation } \\
\text { and stunting }\end{array}$ & $\begin{array}{l}\text { Severe leaf malformation } \\
\text { and stunting }\end{array}$ & $\begin{array}{l}\text { Severe leaf malformation } \\
\text { and stunting }\end{array}$ & $\begin{array}{l}\text { Severe leaf malformation } \\
\text { and stunting }\end{array}$ \\
\hline & Cucumber & Mottle & Mottle & Mosaic & Mottle \\
\hline & Melon & Mottle & Mottle & Mottle & Mosaic and mottle \\
\hline \multirow[t]{4}{*}{$\overline{\mathrm{CMV}-15.5 \mathrm{Po}}$} & Onion & Mild leaf malformation & Mild leaf malformation & Mild leaf malformation & Mild leaf malformation \\
\hline & Garlic & $\begin{array}{l}\text { Severe leaf malformation } \\
\text { and stunting }\end{array}$ & $\begin{array}{l}\text { Severe leaf malformation } \\
\text { and stunting }\end{array}$ & $\begin{array}{l}\text { Severe leaf malformation } \\
\text { and stunting }\end{array}$ & $\begin{array}{l}\text { Severe leaf malformation } \\
\text { and stunting }\end{array}$ \\
\hline & Cucumber & Mottle & Mottle & Mottle & Mottle \\
\hline & Melon & Mottle & Mottle & Mottle & Mottle \\
\hline
\end{tabular}

a Mottle was considered mild, while mosaic was considered as a more severe symptom.

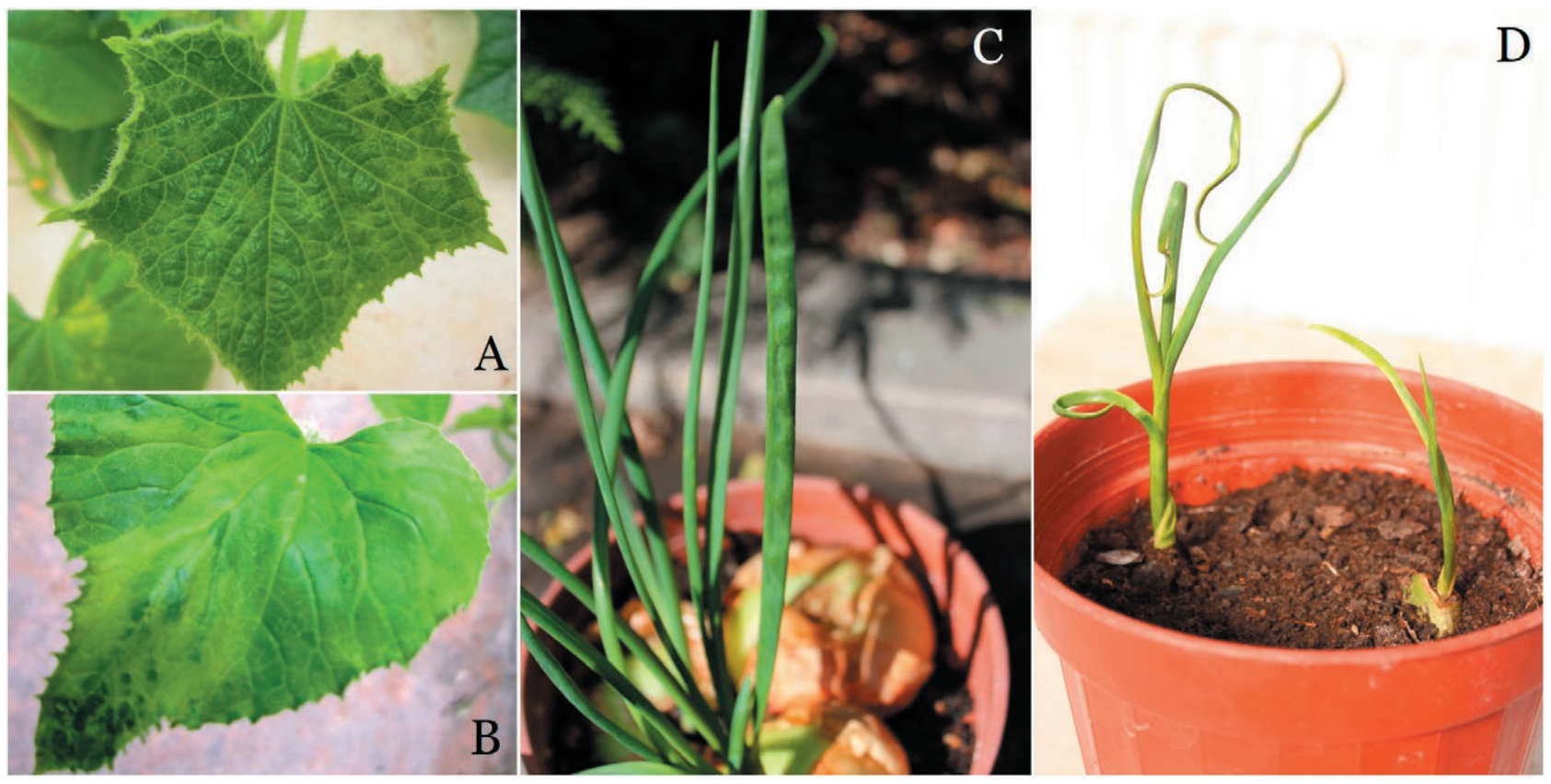

Figure 2. Symptoms on plants mechanically inoculated with two CMV isolates from onion. A. Mosaic on cucumber inoculated with CMV14.3Po, B. Mosaic and mottle on melon inoculated with CMV-14.3Po, C. Mild leaf malformation on onion inoculated with CMV-15.5Po, D. Severe leaf malformation and stunting on garlic inoculated with CMV-15.5Po.

tity analyses of this study. Phylogenetic analyses on this region were useful for classification of CMV isolates into subgroups IA, IB, and II (Roossinck et al., 1999). The two onion isolates belonged to subgroups IA according to phylogenetic analysis in the present study.

Isolates that have high genomic similarities to CMV14.3Po and CMV-15.5Po were identified from different plant species from several families. As comparison, four isolates in Group 3 (Ly2-CMV, C2, C4, and C6) were all identified from Lilium spp. Results from phylogenetic and similarity analyses also showed that CMV isolates with genome signature similar to CMV-14.3Po and CMV-15.5Po naturally had wide host ranges, and had been found in a broad geographic area, comprising Mediterranean, European, and East Asian countries. CMV should therefore be included in future virus surveys of Allium conducted in these regions, especially where CMV was known to be prevalent. 


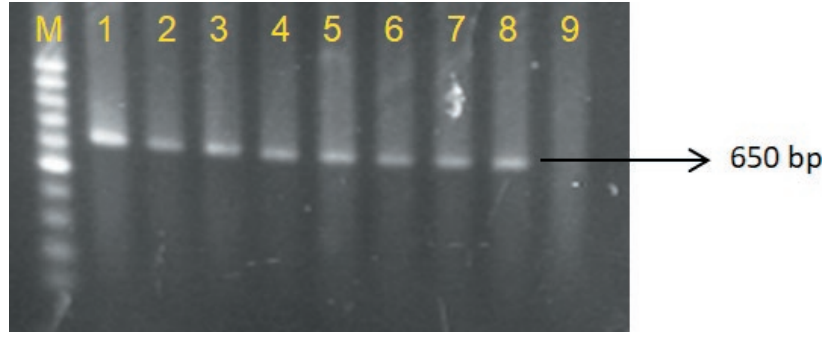

Figure 3. Gel from extracts of onion, garlic, cucumber, and melon plants mechanically inoculated with two onion isolates of CMV in the host indexing study gave positive results in RT-PCR to amplify partial RNA2 of CMV (650 bp). Isolate CMV-14.3Po in lane 1. onion, lane 2. garlic, lane 3. cucumber, and lane 4. Melon. Isolate CMV-15.5Po in lane 5. onion, lane 6. garlic, lane 7. cucumber, lane 8. Melon. Lane 9. negative control (uninoculated onion). Lane $\mathrm{M}=$ 100 bp DNA ladder marker (Thermo Fisher Scientific).

Partial RNA3 sequences of CMV-14.3Po and CMV15.5Po shared high similarities to two other Turkish CMV isolates (TUR84 and TUR86) identified from Rapistrum rugosum (Oshima et al., 2016). This provided more evidence to the previous suggestion based on phylogenetic analyses of partial RNA2, that onion isolates were probably transmitted from $R$. rugosum, or other weed species, in onion fields. During the survey that was conducted in Ankara province, only two of 210 onion samples tested positive for CMV infections. This low infection rate may have been due to absence of aphid vectors (Santosa and Ertunc, 2020). The two onion isolates were found in two different fields close to each other during a survey that covered a wide area. The isolates were therefore likely to only spread locally, because natural mechanical transmission in onion was difficult.

CMV-14.3Po and CMV-15.5Po were shown to be mechanically transmissible to onion, garlic, cucumber, and melon, based on host indexing results. CMV-G was also reported to be transmitted to onion and cucumber by mechanical inoculation. Similar to CMV-14.3Po and CMV-15.5Po, CMV-G produced severe symptoms on garlic (Stefanac, 1980). CMV-G caused severe symptom (necrotic streaks) on onion, contrary to CMV-14.3Po and CMV-15.5Po that only produced mild leaf malformation on onion. These results probably showed response of different onion varieties to CMV isolates. The mild leaf malformation on inoculated onions was consistent with symptoms on inoculum sources (samples that were naturally infected by CMV-14.3Po and CMV-15.5Po) (Santosa and Ertunc, 2020). Onion isolates mostly only caused mild symptom (mottle) on inoculated cucumber and melon, with only one of each cucumber and melon plants developing severe symptoms (mosaic).
Based on low infection rate and mild symptom severity, it can be shown that CMV is a minor virus that does not pose serious threats to onion production. CMV could be a threat for garlic cultivation, since it caused severe damage to garlic plants, and garlic vegetative propagation would easily transmit viruses to next generations. However, CMV infection on garlic was determined to be rare in a survey (Fidan, 2010). Severe symptoms on garlic which could eliminate the possibility for infected plants to become planting material, and the difficulty to transmit CMV-G by aphids, were thought to be the reasons for rare CMV infection on garlic (Stefanac and Milicic, 1992).

Phylogenetic and similarity analyses and host indexing that were performed on CMV-14.3Po and CMV15.5Po revealed knowledge of CMV isolates that naturally infect onion, which was lacking prior to this study. However, information on distribution, transmission, economic importance and genomic diversity of CMV in onion and other Allium spp. is still needed to be further investigated.

\section{ACKNOWLEDGEMENT}

This research was funded by the Scientific Research Projects Coordinator of Ankara University (Project No. 18H0447001, "Detection of Viral Infection Sources on Onion Production Areas").

\section{LITERATURE CITED}

Abraham A.D., Kidanemariam D.B., Holton T.A., 2019. Molecular identification, incidence and phylogenetic analysis of seven viruses infecting garlic in Ethiopia. European Journal of Plant Pathology 55: 181-191. https://doi.org/10.1007/s10658-019-01760-9

Alfaro-Fernandez A., Villaescusa F.J., Hermoso de Mendoza A., Ferrandiz J.C., Sanjuan S., Font San Ambrosio M.I., Unpublished. First report of aster yellows and stolbur phytoplasma infecting commercial leek (Allium porrum L.) in Spain.

Bag S., Schwartz H.F., Cramer C.S., Havey M.J., Pappu H.R., 2015. Iris yellow spot virus (Tospovirus: Bunyaviridae): From obscurity to research priority. Molecular Plant Pathology 16(3): 224-237. https://doi. org/10.1111/mpp.12177

Boccard F., Baulcombe D., 1993. Mutational analysis of cis acting sequences and gene function in RNA3 of Cucumber mosaic virus. Virology 193: 563-578. https://doi.org/10.1006/viro.1993.1165 
Brunt A.A., Crabtree K., Dallwitz M.J., Gibbs A.J., Watson L., 1996. Plant Viruses Online: Description and Lists from the VIDE Database. Cucumber mosaic cucumovirus. Available at: http://bio-mirror.im.ac.cn/ mirrors/pvo/vide/descr267.htm. Accessed January 31, 2020.

Bujarski J., Gallitelli D., García-Arenal F., Pallás V.B., Palukaitis P., ... ICTV Report Consortium., 2019. ICTV Virus Taxonomy Profile: Bromoviridae. Journal of General Virology 100: 1206-1207. https://doi. org/10.1099/jgv.0.001282

Chen J., Wei C.B., Zheng H.Y., Shi Y.H., Adams M.J., ... Chen J.P., 2005. Characterisation of the welsh onion isolate of Shallot yellow stripe virus from China. Archives of Virology 150: 2091-2099. https://doi. org/10.1007/s00705-005-0580-3

De Blas C., Borja M.J., Saiz M., Romero J., 1994. Broad spectrum detection of Cucumber mosaic virus (CMV) using the Polymerase Chain Reaction. Journal of Phytopathology 141(3): 323-329. https://doi. org/10.1111/j.1439-0434.1994.tb01476.x

Dovas C.I., Volvas C., 2003. Viruses infecting Allium spp. in Southern Italy. Journal of Plant Pathology 85(2): 135. http://dx.doi.org/10.4454/jpp.v85i2.1022

Fajardo T.V.M., Nishijima M., Buso J.A., Torres A.C., Ávila A.C., Resende R.O., 2001. Garlic viral complex: identification of potyviruses and carlavirus in central Brazil. Fitopatologia Brasileira 26: 619-626. https:// doi.org/10.1590/S0100-41582001000300007

Fidan H., 2010. Sarımsak, soğan ve pirasadaki virüs hastalıklarını saptanması ve Taşköprü 56 sarımsak tipinin en yaygın virüse karşı reaksiyonunun belirlenmesi. PhD Thesis, Cukurova University, Adana, Turkey, 163 pp (in Turkish).

Finetti Sialer M.M., Cillo F., Barbarossa L., Gallitelli D., 1999. Differentiation of Cucumber mosaic virus subgroups by RT-PCR RFLP. Journal of Plant Pathology 81(2): 145-148. http://dx.doi.org/10.4454/jpp. v81i2.1059

Gera A., Lesemann D.E., Cohen J., Franck A., Levy S., Salomo R., 1997. The natural occurrence of Turnip Mosaic Potyvirus in Allium ampeloprasum. Journal of Phytopathology 145(7): 289-293. https://doi. org/10.1111/j.1439-0434.1997.tb00403.x

Hall B.G., 2013. Building phylogenetic trees from molecular data with MEGA. Molecular Biology and Evolution 30(5): 1229-1235. https://doi.org/10.1093/molbev/mst012

Hayes R.J., Buck K.W., 1990. Complete replication of a eukaryotic virus RNA in vitro by a purified RNAdependent RNA Polymerase. Cell 63(2): 363-368. https://doi.org/10.1016/0092-8674(90)90169-f
Hill S.A., 1984. Methods in Plant Virology. Blackwell Scientific Publications, Oxford, United Kingdom, 167 pp.

Hull R., 2009. Mechanical inoculation of plant viruses. Current Protocols in Microbiology 13: 16B.6.116B.6.4. https://doi.org/10.1002/9780471729259. mc16b06s 13

Majumder S., Baranwal V.K,. Joshi S., 2008. Simultaneous detection of Onion yellow dwarf virus and Shallot latent virus in infected leaves and cloves of garlic by Duplex RT-PCR. Journal of Plant Pathology 90(2): 371-374. https://doi.org/10.1007/s13337-010-0008-X

Muhire B.M., Varsani A., Martin D.P., 2014. SDT: A virus classification tool based on pairwise sequence alignment and identity calculation. PloS One 9(9): e108277. https://doi.org/10.1371/journal. pone. 0108277

Nam M., Lee Y., Park C.H., Lee M., Bae Y., ... Lee S., 2015. Development of multiplex RT-PCR for simultaneous detection of garlic viruses and the incidence of garlic viral disease in garlic genetic resources. The Plant Pathology Journal 31(1): 90-96. https://doi. org/10.5423/PPJ.NT.10.2014.0114

Ohno H., Hase S., Ehar, Y., 1997. Analysis of the $\mathrm{pH}$ effect on infectivity of Cucumber mosaic virus-A possible role of Ribonuclease. Annals of the Phytopathological Society of Japan 63: 445-449.

Ohshima K., Matsumoto K., Yasaka R., Nishiyama M., Soejima K., ... Takeshita M., 2016. Temporal analysis of reassortment and molecular evolution of Cucumber mosaic virus: Extra clues from its segmented genome. Virology 487: 188-197. https://doi. org/10.1016/j.virol.2015.09.024

Palukaitis P., Garcia-Arenal F., 2003. Cucumoviruses. Advances in Virus Research 62: 241-323. https://doi. org/10.1016/s0065-3527(03)62005-1

Parrano L., Afunian M., Pagliaccia D., Douhan G., Vidalakis G., 2012. Characterization of viruses associated with garlic plants propagated from different reproductive tissues from Italy and other geographic regions. Phytopathologia Mediterranea 51(3): 549565. https://doi.org/10.14601/Phytopathol_Mediterr-10479

Presting G.G., Smith O.P., Brown C.R., 1995. Resistance to Potato leafroll virus in Potato plants transformed with the Coat protein gene or with vector control constructs. Phytopathology 85: 436-442. https://doi. org/10.1094/Phyto-85-436

Roossinck M.J., Zhang L., Hellwald K.H., 1999. Rearrangements in the 5' nontranslated region and phylogenetic analyses of Cucumber mosaic virus RNA 3 indicate radial evolution of three subgroups. Journal 
of Virology 73(8): 6752-6758. http://www.ncbi.nlm. nih.gov/pmc/articles/pmc112760/

Santosa A.I., Ertunc F., 2020. Identification, molecular detection and phylogenetic analysis of four viruses infecting Allium cepa in Ankara province, Turkey. Journal of Plant Diseases and Protection 127(4): 561569. https://doi.org/10.1007/s41348-020-00347-5

Sevik M.A., Akcura C., 2013. Viruses occurring in onion crop in Amasya province, the major onion producing region in Turkey. Indian Journal of Virology 24(1): 78-81. https://doi.org/10.1007/s13337-012-0114-z

Shahraeen N., Lesemann D.E., Ghotbi T., 2008. Survey for viruses infecting onion, garlic and leek crops in Iran. Bulletin OEPP/EPPO Bulletin 38: 131-135. https://doi.org/10.1111/j.1365-2338.2008.01198.x

Stefanac Z., 1980. Cucumber mosaic virus in Garlic. Acta Botanica Croatica 39: 21-26.

Stefanac Z., Milicic D., 1992. Observations on infection of garlic (Allium sativum L.) with Cucumber mosaic virus. Acta Botanica Croatica 51: 1-5.

Sujitha A., Bhaskara Reddy B.V., Sivaprasad Y., Usha R., Sai Gopal D.V.R., 2012. First report of Groundnut bud necrosis virus infecting onion (Allium cepa). Australasian Plant Disease Notes 7: 183-187. https://doi. org/10.1007/s13314-012-0080-8

Tamura K., 1992. Estimation of the number of nucleotide substitutions when there are strong Transition-Transversion and $\mathrm{G}+\mathrm{C}$-content biases. Molecular Biology and Evolution 9(4): 678-687. https://doi.org/10.1093/ oxfordjournals.molbev.a040752

Tomassoli L., Tiberini A., Masenga V., Vicchi V., Turina M., 2009. Characterization of Iris yellow spot virus isolates from onion crops in Northern Italy. Journal of Plant Pathology 91(3): 733-739.

Ward L.I., Perez-Egusquiza Z., Fletcher J.D., Clover G.R.G., 2009. A survey of viral diseases of Allium crops in New Zealand. Australasian Plant Pathology 38: 533-539. https://doi.org/10.1071/AP09039 